\title{
PENGEMBANGAN SISTEM PENCARIAN RUTE TERCEPAT LOKASI PENJUALAN SOUVENIR KHAS LOMBOK DENGAN MENGGUNAKAN FUNGSI WAYPOINT DAN METODE HEURISTIK GREEDY DI KOTA MATARAM BERBASIS SIG
}

\author{
(Development of GIS-based Fastest Route Search Location of Lombok Souvenir \\ Sales by Using Waypoint Function And Greedy Heuristic Method In Mataram City)
}

\author{
Anang Nugroho, Wirarama Wedashara, dan Ariyan Zubaidi* \\ Program Studi Teknik Informatika, Fakultas Teknik, Universitas Mataram. \\ Jl. Majapahit 62, Mataram, Lombok, NTB-INDONESIA. \\ Email: AnangNugroho13@gmail.com, wirarama ,zubaidi13[@unram.ac.id]
}

\begin{abstract}
The purpose of this research is to build web based geographical information system that facilitate domestic and foreign tourists to search souvenir shops in Lombok, where tourists can search 1-3 categories of existing stores and search for the closest route from the user's position based on the search category. This system use the heuristic greedy method for route search, where geolacation is used to get the user's location which is used as a starting location for route search by souvenirs and use as a route by using the waypoint function used to create routes with more than one destination location. We use blackbox, whitebox and MOS (Mean Opinion Score) as system testing. The result of blackbox testing showed the functions in the system has been running nicely without having any errors. Whitebox test results showed that the system search results match the search results manually. We got 32\% strongly agreed, 52\% agreed and $16 \%$ neutral opinions using MOS from the user side and we got 36\% strongly agreed, 38\% agreed and 26\% neutral opinions from the admin side.
\end{abstract}

Keyword: Codelgniter, waypoint, Geolocation, google maps, Heuristic, Greedy.

*Penulis Korespondensi

\section{Pendahuluan}

Teknologi informasi memberikan banyak kemudahan bagi penggunanya baik itu perseorangan maupun organisasi. Banyak instansi dan masyarakat maju yang telah memanfaatkan teknologi informasi untuk memperoleh informasi. Salah satu perkembangan teknologi yang telah berkembang pesat, yaitu teknologi internet. Dengan kemajuan teknologi internet, berbagai alternative tersedia dalam menyajikan suatu informasi, salah satunya adalah berbasis website. Manfaat yang diberikan adalah efektivitas dalam proses pengolahan informasi, selain itu, sistem informasi berbasis web memberikan tampilan menarik, user friendly dan dapat diakses melalui berbagai perangkat yang dimiliki seperti laptop, komputer desktop, smartphone dan yang lainnya.

Saat ini pulau Lombok merupakan destinasi pariwisata yang diminati oleh banyak wisatawan. Banyak wisatawan domestik ataupun mancanegara memilih pulau Lombok sebagai tujuan wisata, berdasarkan data kunjungan wisatawan dari dinas pariwisata pada tahun 2019 lombok memiliki jumlah kunjungan yang selalu bertambah setiap bulannya, melihat hal itu banyak penduduk lokal yang memulai usaha dengan menjual produk khas pulau Lombok untuk dijadikan oleh - oleh, mulai dari jajanan, pakaian, dan juga kesenian khas Lombok.

Kebutuhan akan informasi lokasi penjualan oleh oleh khas Lombok tentunya dibutuhkan oleh wisatawan yang ingin membawa cinderamata khas 
pulau Lombok, akan tetapi kebutuhan akan informasi tentang lokasi dari toko oleh - oleh masih belum ada dan hanya terbatas pada sosial media dimana wisatawan hanya dapat mengetahui lokasi akan toko oleh - oleh yang direkomendasikan oleh wisatawan lainnya ataupun toko oleh - oleh yang melakukan promosi pada sosial media, sehingga wisatawan hanya mengetahui lokasi toko oleh - oleh tersebut walaupun lokasi toko tersebut jauh dari tempat wisatawan itu berada dan terkadang cinderamata yang diinginkan oleh wisatawan berbeda dengan informasi yang ada. Wisatawan juga mendapatkan informasi melalui google maps akan tetapi terdapat kekurangan dimana google maps dimana google maps hanya menampilkan toko oleh - oleh dari seluruh data yang ada dalam database dalam radius tertentu dari posisi pengguna sehingga pengguna masih harus mencari toko oleh oleh yang diinginkan pengguna serta memasukan titik kordinat dari tujuan toko secara manual untuk mendapat rute menuju lokasi toko oleh-oleh.

Sehingga perlu adanya suatu sistem informasi yang dapat memberikan informasi berupa lokasi penjualan oleh - oleh khas Lombok sehingga dapat membantu wisatawan domestik maupun wisatawan mancanegara untuk mendapatkan informasi tentang lokasi penjualan oleh - oleh disekitarnya. Diperlukan juga fitur geografis yang mampu menggambarkan rute perjalanan menuju lokasi yang dapat memudahkan wisatawan untuk mengetahui arah menuju lokasi yang diinginkan .

Untuk menyelesaikan permasalahan tersebut, maka penulis membuat suatu sistem informasi geografis pencarian rute terdekat took oleh-oleh. Sistem ini merupakan aplikasi pemetaan lokasi toko oleh - oleh dan pencarian lokasi toko oleh - oleh menggunakan metode heuristik Greedy yang digunakan untuk menentukan lokasi toko terdekat. Pada sistem ini akan mengambil titik kordinat pengguna dengan menggunakan fungsi geolocation untuk digunakan sebagai titik awal pencarian toko dan pengguna akan memasukkan jenis kategori toko jajanan, kesenian, dan pakaian sesuai dengan kebutuhan maka sistem nantinya akan menampilkan rute dengan tujuan satu lokasi oleh - oleh atau lebih dari satu lokasi oleh - oleh sesuai dengan kategori yang dimasukkan pengguna. Sistem ini membutuhkan data dari lokasi oleh - oleh yang ada yang di kota Mataram sehingga pengumpulan data menggunakan cara observasi menuju lokasi untuk mendapatkan data lokasi serta data toko pada setiap toko oleh - oleh dikota Mataram.

\section{TINJAUAN PUSTAKa}

Pada penelitian [1]merupakan aplikasi web-GIS yang menampilkan informasi kuliner terdekat dengan menggunakan fungsi haversine untuk mencari lokasi kuliner terdekat dengan radius yang telah ditentukan pengguna dan dengan menggunakan lokasi pengguna sebagai center untk pencarian tersebut. Sehingga pengguna dapat mengetahui lokasi kuliner terdekat dari titik lokasi pengguna dalam radius tertentu.

Pada penelitian [2]dilakukan penelitian untuk mencari rute terdekat untuk menentukan jalur terpendek pengiriman barang kekantor pos-kantor pos cabang medan dengan menggun akan metode heuristik $A^{*}$, sehingga memudahkan petugas atau kurir kantor pos untuk menentukan jalur mana yang terpendek untuk mengantarkan barang akan dikirim.

Pada penelitian [3] algoritma heuristic Greedy digunakan untuk optimasi kunjungan tempat wisata. Algoritma ini dapat mencari jalur terpendek pada sekumpulan node dan meletakkannya pada solusi yang disediakan atau dapat dituliskan dengan notasi big-O, $\mathrm{O}(\mathrm{n} 2 \log 2(\mathrm{n}))$. Permasalahan ini masuk pada TSP (Travelling Salesman Problem) di dalam algoritma Greedy. Pada kasus TSP persyaratannya adalah semua tujuan akan dikunjungi, dan setiap tempat hanya dikunjungi.

Pada penelitian [4] menggunakan algoritma Bellman-Ford, dimana ketika user membuka aplikasi ini user dapat langsung melihat lokasi UMKM yang tersebar di Kota Medan kemudian ketika user sudah memilih lokasi UMKM yang ingin dituju, maka algoritma Bellman-Ford akan memproses permintaan user dan mencari 3 rute terdekat menuju UMKM yang ingin dituju user dengan menampilkan Google Maps disertai dengan garis yang menghubungkan antara lokasi user dengan lokasi UMKM sebagai outputnya. Dengan hasil pengujian sistem bahwa perhitungan jarak terpendek sangat bergantung kepada relasi titik yang telah di-input ke dalam database. Jika salah satu titik menuju UMKM tersebut tidk terhubung maka tidak ada rute yang akan tampil pada sistem.

Pada penelitian [5] dilakukan penelitian untuk mencari rute terpendek menuju POM bensin terdekat di kota Semarang dengan menggunakan metode Dijkstra, sehingga memudahkan pengguna untuk mencari POM bensin terdekat. Dari pengujian sistem, didapatkan hasil pencarian rute terpendek dengan memanfaatkan algoritma Dijkstra dengan basis sistem informasi geografis (SIG).

Pada penelitian [6] dikembangkan GIS dengan kemampuan untuk pencarian dan menampilkan informasi berbagai sarana kesehatan masyarakat 
dengan menggunakan algoritma Depth first search. Sistem dilengkapi dengan fitur pencarian rute terdekat fasilitas kesehatan masyarakat. Sistem dapat memenuhi kebutuhan akan informasi Rumah Sakit terdekat bagi masyakarat yang perlu akses dengan cepat.

Pada penelitian [7] dilakukan pencarian rute jalur distribusi minuman PT.COCA-COLA Kota Padang dengan menggunakan metode Dijkstra, sehingga memudahkan pengguna untuk menentukan jalur distribusi. Hasilnya, sistem mampu memberikan informasi bagi PT. Coca Cola mengenai jalur mana yang dapat ditempuh untuk distribusi produknya berdasarkan rute terpendek yang dihasilkan oleh algoritma Dijkstra yang digunakan.

Pada penelitian [8] dilakukan penelitian untuk mencari rute terdekat menuju indekos pada Kelurahan Kandang Limun dan Beringin Raya dengan menggunakan metode Dijkstra, sehingga memudahkan pengguna untuk menentukan rute menuju indekos terdekat. Dengan hasil penilaian terhadap variabel tampilan dengan nilai rata-rata 3.31 dari 4, penilaian terhadap variabel Kinerja Sistem dengan nilai rata-rata 3.1875 dari 4 dan penilaian terhadap variabel kemudahan pengguna dengan nilai rata-rata 3.125 dari 4.

Pada penelitian [9] dilakukan penelitian untuk mencari rute terdekat menuju perusahaan mebel di kota Jepara dengan menggunakan metode $A^{*}$, sehingga memudahkan pengguna untuk mencari rute menuju perusahaan mebel terdekat. Pengujian dilakukan dengan metode Black Box Testing. Sistem mampu menemukan rute terpendek menggunakan Algoritma $A^{*}$ (Star) dari titik awal menuju titik akhir dengan valid.

Pada penelitian [10] dilakukan penelitian untuk mencari rute terdekat menuju Apotek di kota Kendari dengan menggunakan metode Floyd-Warshall, sehingga memudahkan masyarakat untuk mencari rute menuju Apotek terdekat. Dengan hasil Pengujian dengan menggunakan metode white box diperoleh hasil dengan tingkat akurasi $100 \%$ dari perbandingan keluaran sistem dengan perhitungan manual.

Berdasarkan hasil penelitian diatas dapat dilihat banyak metode yang digunakan untuk pencarian rute, akan tetapi tidak ada penelitian untuk mencari rute lebih dari satu tujuan. Penggunaan dan pemilihan metode Greedy dikarenakan untuk mempercepat waktu penentuan lokasi yang akan dikunjungi

\section{Metodologi Penelitian}

Pada pembuatan sistem informasi geografis ini membutuhkan beberapa alat dan bahan yang terdiri dari perangkat keras (hardware) dan perangkat lunak (software).

Laptop yang akan digunakan sebagai media pembangunan aplikasi dan untuk uji coba yang akan digunakan oleh admin.

Pada pembangunan sistem pencarian rute tercepat lokasi penjualan souvenir khas Lombok ini menggunakan data lokasi penjualan souvenir khas Lombok dimana data yang diperlukan adalah data lokasi berupa latitude dan longititude, nama toko, alamat, dan jenis oleh - oleh yang digunakan untuk menampilkan data tersebut kedalam google maps API dan untuk proses pencarian rute terdekat sesuai dengan yang diinginkan pengguna sehingga pengumpulan data dilakukan dengan cara observasi pada setiap toko oleh - oleh di kota Mataram.

Perangkat lunak yang dibutuhkan untuk membuat aplikasi yaitu:

a. OS (operating system), pada pembuatan aplikasi digunakan Windows 10 32-bit sebagai media untuk menjalankan software-software yang lain yang akan digunakan untuk membuat sistem.

b. Sublime Text merupakan text editor yang akan digunakan untuk membuat code program dari aplikasi yang akan dibuat pada tugas akhir ini.

c. Menggunakan PHP sebagai bahasa pemrogramannya

d. Codelgniter digunakan sebagai framework pembuatan aplikasi berupa website yang akan mempermudah dalam pembangunan aplikasi.

e. XAMPP merupakan software web server apache yang didalamnya terdapat server MySQL yang akan digunakan sebagai server dalam pembuatan aplikasi dan digunakan untuk mengelola database yang dibutuhkan aplikasi.

f. Microsoft office 2010 digunakan untuk penyusunan laporan.

\subsection{Metode Algoritma Heurisktik Greed}

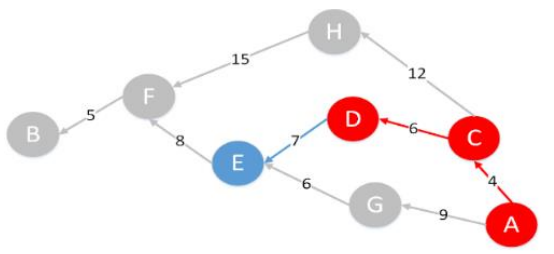

Gambar 1 Algoritma Heuristik Greedy.

\subsection{Alat dan Bahan}

http://jtika.if.unram.ac.id/index.php/JTIKA/ 
Pada gambar 1 adalah Algoritma heuristic Greedy yang merupakan algoritma yang memecahkan masalah langkah per langkah, pada setiap langkah:

a. Mengambil pilihan yang terbaik yang dapat diperoleh pada saat itu tanpa memperhatikan konsekuensi ke depan.

b. Berharap bahwa dengan memilih optimum lokal pada setiap langkah akan berakhir dengan optimum global.

\section{Langkah-langkah Algoritma heuristic Greedy:}

a. Himpunan kandidat, himpunan ini berisi seluruh elemen pembentuk solusi

b. Himpunan solusi, berisi kandidat-kandidat yang terpilih sebagai solusi persoalan

c. Fungsi seleksi, fungsi yang pada setiap langkah memilih kandidat yang paling memungkinkan mencapai solusi optimal

d. Fungsi kelayakan, fungsi yang memeriksa apakah suatu kandidat yang terpilih dapat memberikan solusi yang layak, yaitu kandidat bersama-sama dengan himpunan solusi yang sudah terbentuk tidak melanggar kendala yang ada.

e. Fungsi objektif, fungsi yang memaksimumkan atau meminimumkan nilai solusi[11].

Algoritma heuristic Greedy digunakan didalam sistem ini digunakan untuk menentukan toko oleh oleh yang akan dijadikan tujuan lokasi yang akan dituju sesuai dengan kategori yang dimasukkan.

\subsection{Perancangan Usecase Diagram}

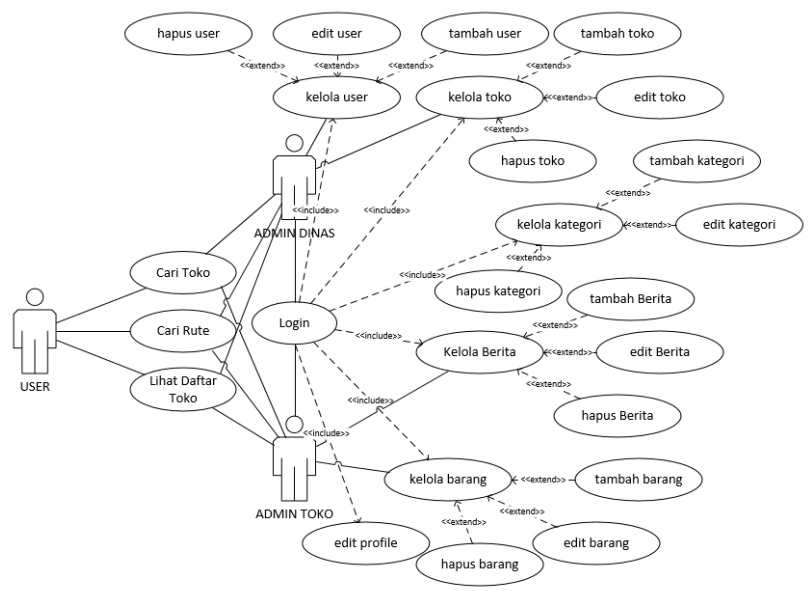

Gambar 2 Usecase diagram sistem

Usecase diagram mendeskripsikan interaksi antara aktor (pengguna aplikasi) dengan sistem yang akan dibuat [12]. Dalam perancangan sistem informasi geografis ini, terdapat tiga aktor yaitu admin dinas Perindag dan admin toko sebagai admin dan wisatawan sebagai user. Behaviour dari setiap actor akan diilustrasikan dalam usecase diagram pada Gambar 2

Pada Gambar 2 terlihat beberapa behavior dari admin dinas, diantaranya kelola user, kelola kategori, kelola toko dan admin toko dapat kelola barang, kelola berita dan mengubah profile, serta user dapat mencari rute dan mencari toko.

\subsection{ERD (Entity Relationship Diagram)}

ERD menggambarkan hubungan relasi antar tabel[13]. Seluruh data akan disimpan pada satu database, sehingga data berada pada satu kesatuan. Perancangan database dilakukan untuk memberikan wadah penyimpanan data dan dapat diolah dengan optiman serta mengurangi duplikasi data. ERD dari sistem ini dapat dilihat pada gambar 3 .

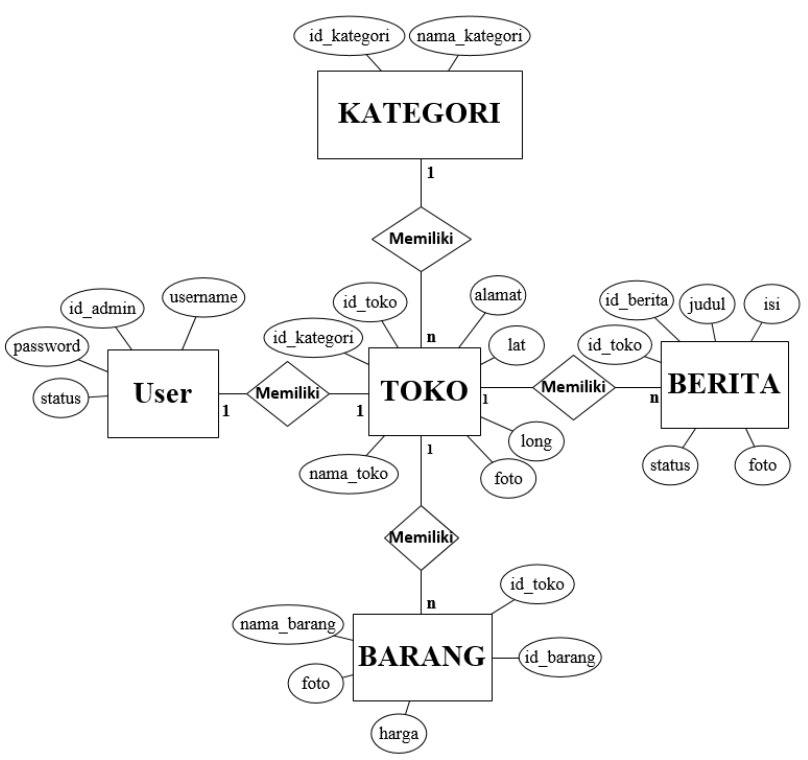

Gambar $3 E R D$ sistem informasi geografis toko oleh oleh

\subsection{Perancangan Layout Sistem}

Tahapan berikutnya adalah desain tata letak website. Desain ini akan menjadi rujukan ketika membuat antarmuka dari sistem yang dapat diakses oleh pengguna system. Rancangan tata letak website ini dapat dilihat pada pada Gambar 4, Gambar 5, Gambar 6, Gambar 7 dan Gambar 8. 


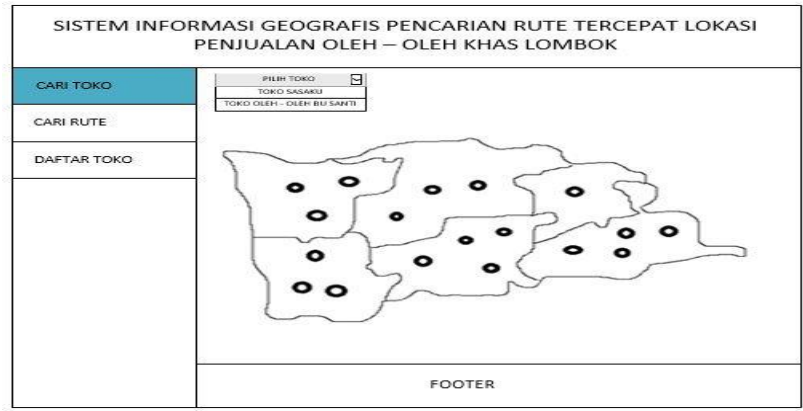

Gambar 4 Rancangan Halaman beranda user.

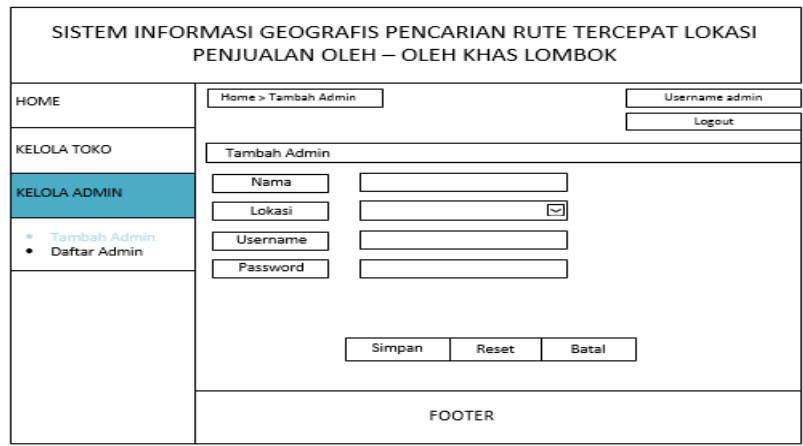

Gambar 5 Rancangan halaman kelola admin.

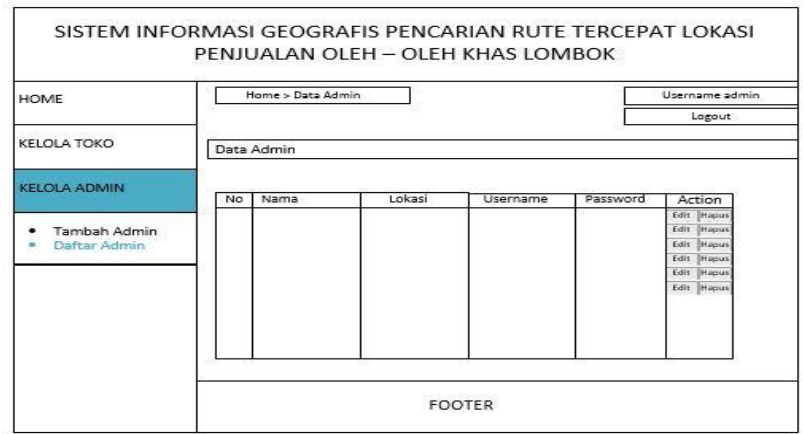

Gambar 6 Rancangan halaman daftar kelola admin

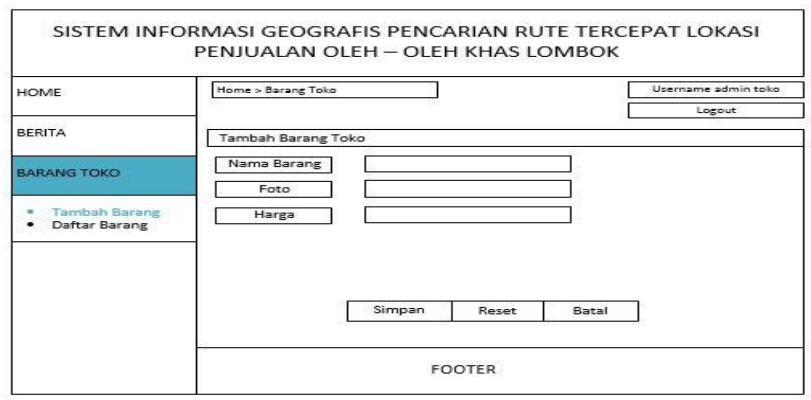

Gambar 7 Rancangan kelola toko sisi admin.

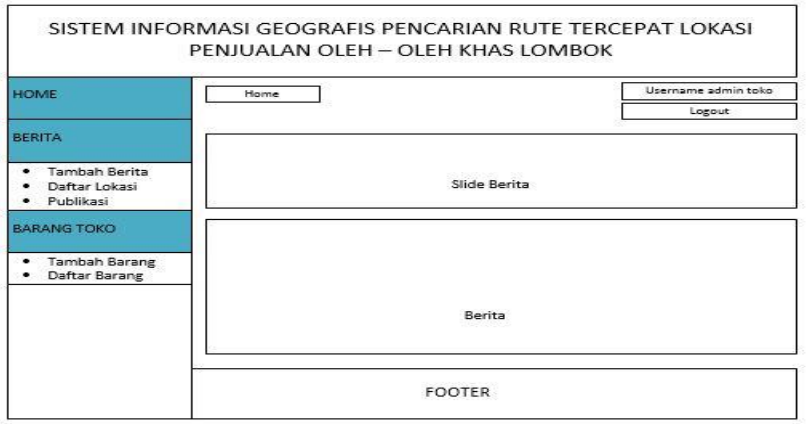

Gambar 8 Rancangan halaman berita sisi user

\subsection{Pengujian Sistem}

Sistem akan diuji dari aspek fungsionalitas dengan menggunakan metode black box. Penggunaan metode black box bertujuan untuk menguji fungsionalitas dari masing-masing fitur yang ada pada sistem, apakah fitur sudah berjalan sebagaimana mestinya atau tidak [14]. Untuk pengujian antarmuka system, digunakan pengujian Mean Opinion Score (MOS). Metode Mean Opinion Score (MOS) dilakukan dengan mengumpulkan penilaian kualitatif secara visual secara subjektif [15].Untuk pengujian cara kerja sistem secara rinci digunakan metode white box.

\section{4. hasil dan Pembahasan}

\subsection{Pembangunan Database}

Pada implementasi database hal pertama yang dilakukan adalah membuat database yang bernama "oleh_oleh". Pada database tersebut terdiri dari lima tabel yaitu, tabel barang, tabel berita, tabel kategori, tabel toko, dan tabel user. Struktur dari database "oleh_oleh" dapat dilihat pada Gambar 9.

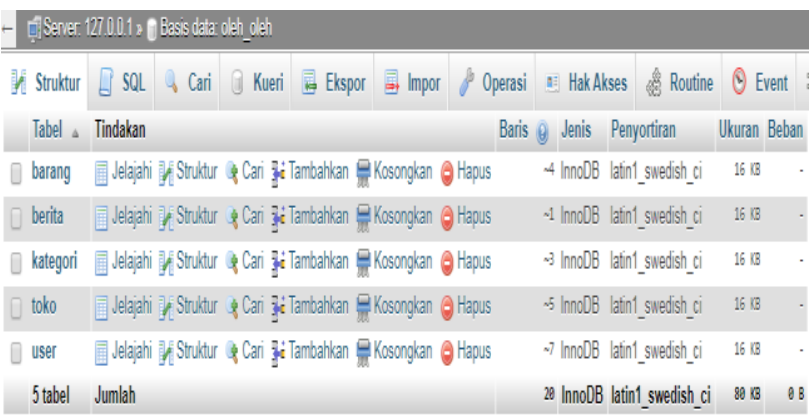

Gambar 9 database sistem.

\subsection{Implementasi Interface}


Antarmuka akan diakses oleh pengguna dan pengguna dapat berinteraksi secara langsung dengan system melalui antarmuka. Implementasi interface dilakukan berdasaran rancangan tata letak yang telak dibuat pada langkah sebelumnya. Pada sistem ini terdapat 2 macam sisi interface, yaitu pada sisi admin dan sisi user.

Hasil implementasi interface sesuai desain ditunjukan oleh Gambar 10, Gambar 11, Gambar 12, Gambar 13, dan Gambar 14.

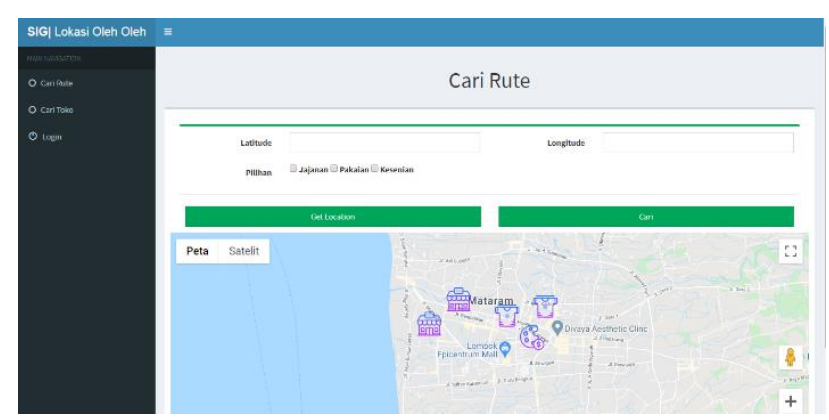

Gambar 10 Interface home

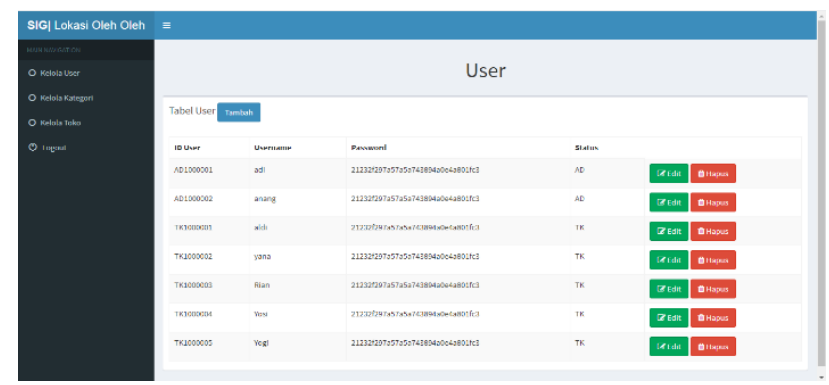

Gambar 11 Interface kelola user sisi admin

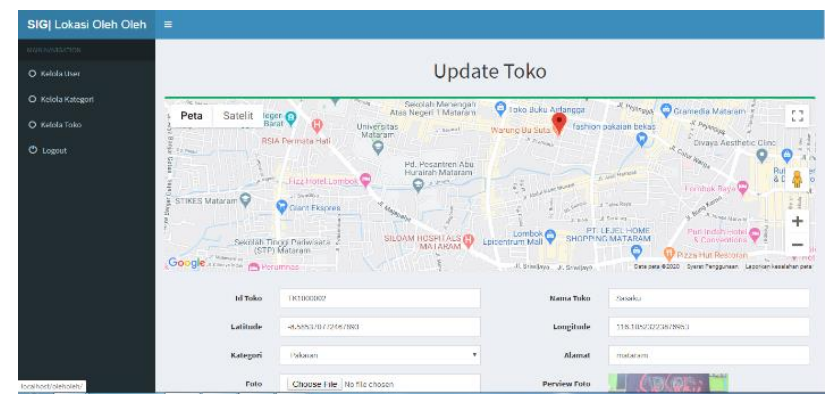

Gambar 12 Interface update sisi admin.

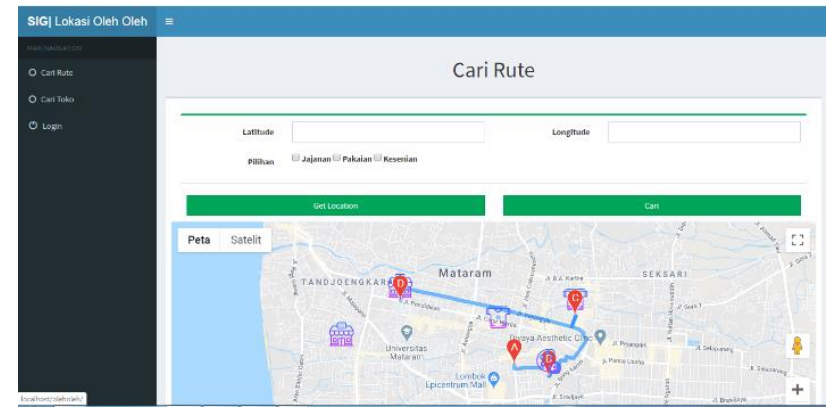

Gambar 13 Interface cari rute sisi user.
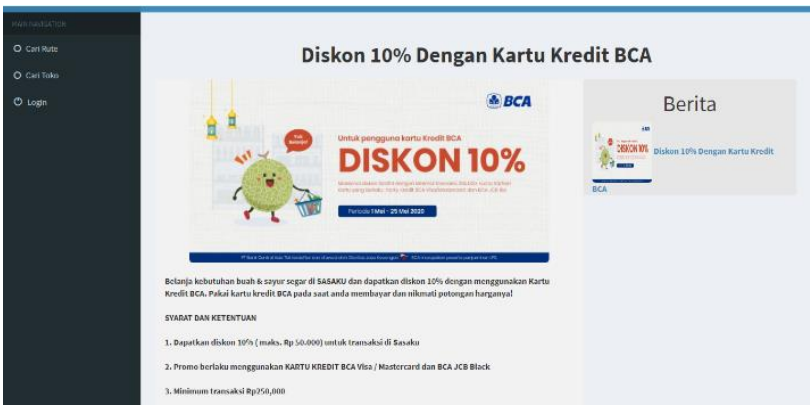

Gambar 14 Interface berita sisi user.

\subsection{Pengujian Sistem}

Sistem akan diuji menggunakan metode black box sedangkan untuk interface akan dilakukan pengujian secara subjektif dengan menggunakan Mean Opinion Score (MOS) dengan melibatkan 30 responden, terdiri dari mahasiswa Universitas Mataram, pegawai dan umum

\subsection{Pengujian Black Box}

Metode pengujian black box dilakukan dengan menguji berbagai fungsi di dalam system degan berbagai macam scenario yang mungkin terjadi pada system.

a. Pengujian Fungsi pada Admin Dinas

1. Fungsi Login Admin

Fungsi login admin diuji untuk mengetahui apakah fungsi yang berjalan pada halaman login admin sudah berjalan dengan benar . Pada pengujian fungsi login Admin terdapat 2 skenario pengujian. Pengujian fungsi login admin akan dijelaskan pada Tabel I. 
TABEL I. PENGUJIAN FUNGSI LOGIN ADMIN.

\begin{tabular}{|l|l|l|l|}
\hline $\begin{array}{l}\text { Skenario } \\
\text { Pengujian }\end{array}$ & $\begin{array}{l}\text { Hasil yang } \\
\text { Diharapkan }\end{array}$ & $\begin{array}{l}\text { Hasil } \\
\text { Pengujian }\end{array}$ & $\begin{array}{l}\text { Kesimp } \\
\text { ulan }\end{array}$ \\
\hline $\begin{array}{l}\text { Username dan } \\
\text { password salah }\end{array}$ & $\begin{array}{l}\text { Proses login } \\
\text { gagal diarahkan } \\
\text { untuk login } \\
\text { kembali }\end{array}$ & Sesuai & Valid \\
\hline $\begin{array}{l}\text { Username } \\
\text { dan password } \\
\text { benar. }\end{array}$ & $\begin{array}{l}\text { Login } \\
\text { berhasil dan } \\
\text { masuk ke } \\
\text { beranda admin. }\end{array}$ & Sesuai & Valid \\
\hline
\end{tabular}

Pada pengujian ini, diberikan beberapa variasi ketika menginput data, pertama apabila username dan password dikosongkan, kedua apabila password diisi dan username dikosongkan dan yang ketiga apabila username diisi dan password dikosongkan. Pada ketiga scenario ini, login tidak bisa dilakukan.

\section{Fungsi pada Kelola User}

Fungsi Kelola User pada sistem ini adalah untuk melihat data semua yang ada di sistem serta bisa melakukan edit, hapus dan tambah data user ke dalam sistem. Pengujian terhadap fungsi kelola user akan dijelaskan pada Tabel II.

TABEL II. PENGUJIAN KELOLA USER

\begin{tabular}{|l|l|l|l|}
\hline $\begin{array}{l}\text { Skenario } \\
\text { Pengujian }\end{array}$ & $\begin{array}{l}\text { Hasil yang } \\
\text { Diharapkan }\end{array}$ & $\begin{array}{l}\text { Hasil } \\
\text { Pengu } \\
\text { jian }\end{array}$ & $\begin{array}{l}\text { Kesim } \\
\text { pulan }\end{array}$ \\
\hline $\begin{array}{l}\text { Padaman kelola } \\
\text { user dapat } \\
\text { dilakukan edit } \\
\text { terhadap data } \\
\text { user yang sudah } \\
\text { tersedia. }\end{array}$ & $\begin{array}{l}\text { Datah } \\
\text { terdaftar } \\
\text { dapat di edit } \\
\text { sesuai dengan } \\
\text { kebutuhan. }\end{array}$ & Sesuai & Valid \\
\hline $\begin{array}{l}\text { Pada Kalaman Kelola } \\
\text { user dapat } \\
\text { melakukan hapus } \\
\text { user }\end{array}$ & $\begin{array}{l}\text { Dang sudah } \\
\text { terdaftar } \\
\text { dapat di } \\
\text { hapus sesuai } \\
\text { dengan } \\
\text { kebutuhan }\end{array}$ & Sesuai & Valid \\
\hline $\begin{array}{l}\text { Pada } \\
\text { halaman Kelola } \\
\text { user dapat } \\
\text { melakukan } \\
\text { tambah data } \\
\begin{array}{l}\text { User ke dalam } \\
\text { sistem }\end{array}\end{array}$ & $\begin{array}{l}\text { Sapat } \\
\text { melakukan } \\
\text { tambah data } \\
\text { User ke dalam } \\
\text { sistem }\end{array}$ & Sesuai & Valid \\
\hline
\end{tabular}

\section{Fungsi Kelola Toko}

Fungsi kelola toko pada sistem ini adalah untuk melihat data semua yang ada di sistem serta bisa melakukan edit, hapus dan tambah data toko ke dalam sistem. Pengujian terhadap fungsi kelola toko akan dijelaskan pada Tabel III.

TABEL III. PENGUJIAN FUNGSI KELOLA TOKO

\begin{tabular}{|l|c|c|c|}
\hline $\begin{array}{l}\text { Skenario } \\
\text { Pengujian }\end{array}$ & $\begin{array}{c}\text { Hasil yang } \\
\text { Diharapkan }\end{array}$ & $\begin{array}{l}\text { Hasil } \\
\text { Penguj } \\
\text { ian }\end{array}$ & $\begin{array}{l}\text { Kesim } \\
\text { pulan }\end{array}$ \\
\hline $\begin{array}{l}\text { Pada } \\
\text { halaman kelola } \\
\text { toko dapat } \\
\text { dilakukan edit } \\
\text { terhadap data } \\
\text { toko yang } \\
\text { sudah tersedia. } \\
\text { terdaftar dapat } \\
\text { di edit sesuai } \\
\text { dengan } \\
\text { kebutuhan. }\end{array}$ & Sesuai & Valid \\
\hline $\begin{array}{l}\text { Pada halaman Kelola } \\
\text { toko dapat } \\
\text { melakukan } \\
\text { hapus toko }\end{array}$ & $\begin{array}{l}\text { Dang sudah } \\
\text { terdaftar dapat } \\
\text { di hapus sesuai } \\
\text { dengan } \\
\text { kebutuhan }\end{array}$ & Sesuai & Valid \\
\hline $\begin{array}{l}\text { Pada } \\
\text { halaman Kelola } \\
\text { toko dapat } \\
\text { melakukan } \\
\text { tambah data } \\
\text { toko ke dalam } \\
\text { sistem }\end{array}$ & $\begin{array}{l}\text { Sapat } \\
\text { melakukan } \\
\text { tambah data } \\
\text { toko ke dalam } \\
\text { sistem }\end{array}$ & Sesuai & Valid \\
\hline
\end{tabular}

\section{Fungsi Kelola Kategori}

Fungsi kelola kategori pada sistem ini adalah untuk melihat data semua yang ada di sistem serta bisa melakukan edit, hapus dan tambah data kategori ke dalam sistem. Pengujian terhadap fungsi kelola kategori akan dijelaskan pada Tabel IV.

TABEL IV. PENGUJIAN FUNGSI KELOLA KATEGORI

\begin{tabular}{|l|l|l|l|}
\hline $\begin{array}{l}\text { Skenario } \\
\text { Pengujian }\end{array}$ & $\begin{array}{l}\text { Hasil yang } \\
\text { Diharapkan }\end{array}$ & $\begin{array}{l}\text { Hasil } \\
\text { Penguj } \\
\text {-ian }\end{array}$ & $\begin{array}{l}\text { Kesim } \\
\text {-pulan }\end{array}$ \\
\hline $\begin{array}{l}\text { Pada } \\
\text { kataman kelola } \\
\text { dilakukan dapat edit } \\
\text { terhadap data } \\
\text { kategori yang } \\
\text { sudah tersedia. }\end{array}$ & $\begin{array}{l}\text { Dategori } \\
\text { sudah } \\
\text { terdaftar } \\
\text { dapat di edit } \\
\text { sesuai dengan } \\
\text { kebutuhan. }\end{array}$ & Sesuai & Valid \\
\hline $\begin{array}{l}\text { Pada Kata } \\
\text { halaman Kelola } \\
\text { kategori dapat }\end{array}$ & $\begin{array}{l}\text { kategori yang } \\
\text { sudah } \\
\text { terdaftar }\end{array}$ & Sesuai & Valid \\
\hline
\end{tabular}




\begin{tabular}{|c|c|c|c|}
\hline $\begin{array}{l}\text { melakukan } \\
\text { hapus kategori }\end{array}$ & $\begin{array}{l}\text { dapat di } \\
\text { hapus sesuai } \\
\text { dengan } \\
\text { kebutuhan }\end{array}$ & & \\
\hline \begin{tabular}{l}
\multicolumn{1}{c}{ Pada } \\
halaman Kelola \\
kategori dapat \\
melakukan \\
tambah data \\
kategori ke \\
dalam sistem
\end{tabular} & $\begin{array}{l}\quad \text { Sistem } \\
\text { dapat } \\
\text { melakukan } \\
\text { tambah data } \\
\text { kategori ke } \\
\text { dalam sistem }\end{array}$ & Sesuai & Valid \\
\hline
\end{tabular}

b. Pengujian Fungsi pada Admin Toko

1. Fungsi Edit Profile

Pengujian dilakukan untuk melihat apakah fungsi yang berjalan pada halaman profile sudah berfungsi dengan baik. Pada pengujian fungsi profile Admin toko terdapat 2 skenario pengujian, ini dapat dilihat pada Tabel V.

TABEL V. PENGUJIAN FUNGSI EDIT PROFILE.

\begin{tabular}{|c|c|c|c|}
\hline $\begin{array}{l}\text { Skenario } \\
\text { Pengujian }\end{array}$ & $\begin{array}{l}\text { Hasil yang } \\
\text { Diharapkan }\end{array}$ & \begin{tabular}{|l|} 
Hasil \\
Pengujian
\end{tabular} & $\begin{array}{l}\text { Kesimp } \\
\text { ulan }\end{array}$ \\
\hline $\begin{array}{l}\quad \text { Data tidak } \\
\text { dilakukan } \\
\text { perubahan }\end{array}$ & $\begin{array}{l}\text { Data dari } \\
\text { Profile toko yang } \\
\text { ada tidak ada } \\
\text { perubahan }\end{array}$ & Sesuai & Valid \\
\hline $\begin{array}{l}\text { Dilakukan } \\
\text { perubahan } \\
\text { terhadap data } \\
\text { profile dari data } \\
\text { yang sudah ada. }\end{array}$ & \begin{tabular}{l}
\multicolumn{1}{c}{ Data dari } \\
Profile toko \\
menampilkan \\
data sesuai data \\
yang dilakukan \\
perubahan.
\end{tabular} & Sesuai & Valid \\
\hline
\end{tabular}

\section{Fungsi pada Kelola Barang}

Fungsi Kelola barang pada sistem ini adalah untuk melihat data semua yang ada di sistem serta bisa melakukan edit, hapus dan tambah data barang ke dalam sistem. Pengujian terhadap fungsi kelola barang akan dijelaskan pada Tabel VI.

TABEL VI. PENGUJIAN KELOLA BARANG

\begin{tabular}{|l|l|l|l|}
\hline $\begin{array}{l}\text { Skenario } \\
\text { Pengujian }\end{array}$ & $\begin{array}{l}\text { Hasil yang } \\
\text { Diharapkan }\end{array}$ & $\begin{array}{l}\text { Hasil } \\
\text { Pengu } \\
\text { jian }\end{array}$ & $\begin{array}{l}\text { Kesim } \\
\text { pulan }\end{array}$ \\
\hline $\begin{array}{l}\text { Pada } \\
\text { halaman kelola } \\
\text { barang dapat } \\
\text { dilakukan edit } \\
\text { terhadap data }\end{array}$ & $\begin{array}{l}\text { Data } \\
\text { terdaftar } \\
\text { dapat di edit } \\
\text { sesuai dengan } \\
\text { kebutuhan. }\end{array}$ & Sesuai & Valid \\
\hline
\end{tabular}

\begin{tabular}{|l|l|l|l|}
\hline $\begin{array}{l}\text { barang yang } \\
\text { sudah tersedia. }\end{array}$ & & \\
\hline $\begin{array}{l}\text { Pada Kalaman Kelola } \\
\text { barang dapat } \\
\text { melakukan } \\
\text { hapus barang }\end{array}$ & $\begin{array}{l}\text { Darang yang } \\
\text { sudah } \\
\text { terdaftar } \\
\text { dapat di } \\
\text { hapus sesuai } \\
\text { dengan } \\
\text { kebutuhan }\end{array}$ & Sesuai & Valid \\
\hline $\begin{array}{l}\text { Pada } \\
\text { halaman Kelola } \\
\text { barang dapat } \\
\text { melakukan } \\
\text { tambah data } \\
\text { barang ke dalam } \\
\text { sistem }\end{array}$ & $\begin{array}{l}\text { Sapat } \\
\text { melakukan } \\
\text { tambah data } \\
\text { barang ke } \\
\text { dalam sistem }\end{array}$ & Sesuai & Valid \\
\hline $\begin{array}{l}\text { Fungi Kelola Berita } \\
\text { Bam }\end{array}$ & & \\
\hline
\end{tabular}

\section{Fungsi Kelola Berita}

Kelola berita pada berfungsi untuk melihat data berita serta bisa dilakukan edit, hapus dan tambah data berita ke dalam sistem. Pengujian terhadap fungsi kelola berita akan dijelaskan pada Tabel VII.

TABEL VII PENGUJIAN FUNGSI KELOLA BERITA

\begin{tabular}{|c|c|c|c|}
\hline $\begin{array}{l}\text { Skenario } \\
\text { Pengujian }\end{array}$ & $\begin{array}{l}\text { Hasil yang } \\
\text { Diharapkan }\end{array}$ & $\begin{array}{l}\text { Hasil } \\
\text { Penguji } \\
\text { an }\end{array}$ & $\begin{array}{l}\text { Kesi } \\
\text { mpul } \\
\text { an }\end{array}$ \\
\hline \begin{tabular}{l}
\multicolumn{2}{c}{ Pada } \\
halaman kelola \\
berita dapat \\
dilakukan edit \\
terhadap data \\
berita yang \\
sudah tersedia.
\end{tabular} & \begin{tabular}{l}
\multicolumn{1}{c}{ Data } \\
berita sudah \\
terdaftar \\
dapat di edit \\
sesuai \\
dengan \\
kebutuhan.
\end{tabular} & Sesuai & Valid \\
\hline $\begin{array}{l}\text { Pada } \\
\text { halaman Kelola } \\
\text { berita dapat } \\
\text { melakukan } \\
\text { hapus berita }\end{array}$ & \begin{tabular}{l}
\multicolumn{1}{c}{ Data } \\
berita yang \\
sudah \\
terdaftar \\
dapat di \\
hapus sesuai \\
dengan \\
kebutuhan
\end{tabular} & Sesuai & Valid \\
\hline \begin{tabular}{l}
\multicolumn{1}{c}{ Pada } \\
halaman Kelola \\
berita dapat \\
melakukan \\
tambah data \\
berita ke dalam \\
sistem
\end{tabular} & \begin{tabular}{l}
\multicolumn{1}{c}{ Sistem } \\
dapat \\
melakukan \\
tambah data \\
berita ke \\
dalam sistem
\end{tabular} & Sesuai & Valid \\
\hline
\end{tabular}




\section{Fungsi Kelola Kategori}

Fungsi kelola kategori pada sistem ini adalah untuk melihat data semua yang ada di sistem serta bisa melakukan edit, hapus dan tambah data kategori ke dalam sistem. Pengujian terhadap fungsi kelola kategori akan dijelaskan pada Tabel VIII

TABEL VIII. PENGUJIAN FUNGSI KELOLA KATEGORI

\begin{tabular}{|c|c|c|c|}
\hline $\begin{array}{l}\text { Skenario } \\
\text { Pengujian }\end{array}$ & $\begin{array}{l}\text { Hasil yang } \\
\text { Diharapkan }\end{array}$ & $\begin{array}{l}\text { Hasil } \\
\text { Pengu } \\
\text { jian }\end{array}$ & $\begin{array}{l}\text { Kesim } \\
\text { pulan }\end{array}$ \\
\hline $\begin{array}{l}\text { Pada } \\
\text { halaman kelola } \\
\text { kategori dapat } \\
\text { dilakukan edit } \\
\text { terhadap data } \\
\text { kategori yang } \\
\text { sudah tersedia. }\end{array}$ & $\begin{array}{l}\quad \text { Data } \\
\text { kategori } \\
\text { sudah } \\
\text { terdaftar } \\
\text { dapat di edit } \\
\text { sesuai dengan } \\
\text { kebutuhan. } \\
\end{array}$ & Sesuai & Valid \\
\hline \begin{tabular}{l}
\multicolumn{1}{c}{ Pada } \\
halaman Kelola \\
kategori dapat \\
melakukan \\
hapus kategori
\end{tabular} & \begin{tabular}{l}
\multicolumn{1}{c}{ Data } \\
kategori yang \\
sudah \\
terdaftar \\
dapat di \\
hapus sesuai \\
dengan \\
kebutuhan
\end{tabular} & Sesuai & Valid \\
\hline \begin{tabular}{l}
\multicolumn{1}{c}{ Pada } \\
halaman Kelola \\
kategori dapat \\
melakukan \\
tambah data \\
kategori ke \\
dalam sistem
\end{tabular} & \begin{tabular}{l}
\multicolumn{1}{c}{ Sistem } \\
dapat \\
melakukan \\
tambah data \\
kategori ke \\
dalam sistem
\end{tabular} & Sesuai & Valid \\
\hline
\end{tabular}

c. Pengujian Fungsi pada User

1. Fungsi Cari Rute

Fungsi Cari Rute dilakukan untuk menguji apakah fungsi yang berjalan pada halaman Cari Rute sudah berjalan dengan baik dan benar pada pengujian fungsi Cari Rute terdapat 2 skenario pengujian. Pengujian fungsi Cari Rute akan dijelaskan pada Tabel IX.

TABEL IX. PENGUJIAN FUNGSI CARI RUTE.

\begin{tabular}{|c|l|r|r|}
\hline \multicolumn{1}{|c|}{$\begin{array}{c}\text { Skenario } \\
\text { Pengujian }\end{array}$} & $\begin{array}{c}\text { Hasil yang } \\
\text { Diharapkan }\end{array}$ & $\begin{array}{r}\text { Hasil } \\
\text { Pengujian }\end{array}$ & $\begin{array}{r}\text { Kes } \\
\text { impula }\end{array}$ \\
\hline \multicolumn{1}{|c|}{$\begin{array}{c}\text { Form } \\
\text { pencarian di isi } \\
\text { dengan data } \\
\text { yang tidak sesuai }\end{array}$} & $\begin{array}{l}\text { Proses Cari } \\
\text { Rute tidak } \\
\text { berhasil dan } \\
\text { akan dirujuk } \\
\text { untuk mengisi }\end{array}$ & Sesuai & Valid \\
\hline
\end{tabular}

\begin{tabular}{|c|c|c|c|}
\hline $\begin{array}{l}\text { Form } \\
\text { pencarian di isi } \\
\text { dengan data } \\
\text { yang sesuai }\end{array}$ & \begin{tabular}{l}
\multicolumn{1}{c}{ Proses Cari } \\
Rute berhasil \\
dan akan dirujuk \\
ke halaman Hasil \\
Cari Rute.
\end{tabular} & Sesuai & i Valid \\
\hline
\end{tabular}

\section{Fungsi Cari Toko}

Pengujian dilakukan untuk menguji apakah fungsi yang berjalan pada halaman Cari Toko sudah berfungsi dengan benar. Terdapat 2 skenario pengujian yang dapat dilihat pada tabel $\mathrm{X}$.

\section{TABEL X. PENGUJIAN FUNGSI CARI TOKO}

\begin{tabular}{|c|c|c|c|}
\hline $\begin{array}{l}\text { Skenario } \\
\text { Pengujian }\end{array}$ & $\begin{array}{l}\text { Hasil yang } \\
\text { Diharapkan }\end{array}$ & $\begin{array}{l}\text { Hasil } \\
\text { Pengujian }\end{array}$ & $\begin{array}{l}\text { Kesimp } \\
\text { ulan }\end{array}$ \\
\hline $\begin{array}{l}\text { Data tidak } \\
\text { dilakukan } \\
\text { perubahan }\end{array}$ & $\begin{array}{l}\text { Proses Cari } \\
\text { Toko tidak } \\
\text { berhasil dan } \\
\text { akan diruiuk }\end{array}$ & Sesuai & Valid \\
\hline $\begin{array}{l}\text { Form } \\
\text { pencarian di isi } \\
\text { dengan data } \\
\text { yang sesuai. }\end{array}$ & \begin{tabular}{l}
\multicolumn{1}{c}{ Proses Cari } \\
Toko berhasil \\
dan akan dirujuk \\
ke halaman Hasil \\
Cari Toko.
\end{tabular} & Sesuai & Valid \\
\hline
\end{tabular}

\subsection{Pengujian White Box.}

Metode pengujian white metode perancangan test case yang menggunakan struktur kontrol dari perancangan prosedural untuk mendapatkan test case. Dengan rnenggunakan metode white box, analis sistem akan dapat memperoleh test case yang Menjamin seluruh independent path dieksekusi paling sedikit satu kali. Independent path adalah jalur dalam program yang menunjukkan paling sedikit satu kumpulan proses ataupun kondisi baru. Berikut fungsi di Sistem Pencarian Rute Tercepat Lokasi Penjualan souvenir khas Lombok dengan menggunakan metode Heuristik greedy dan fungsi WayPoint dan di Kota Mataram seperti pada Gambar 4.15 yang akan diuji menggunakan metode white box: 


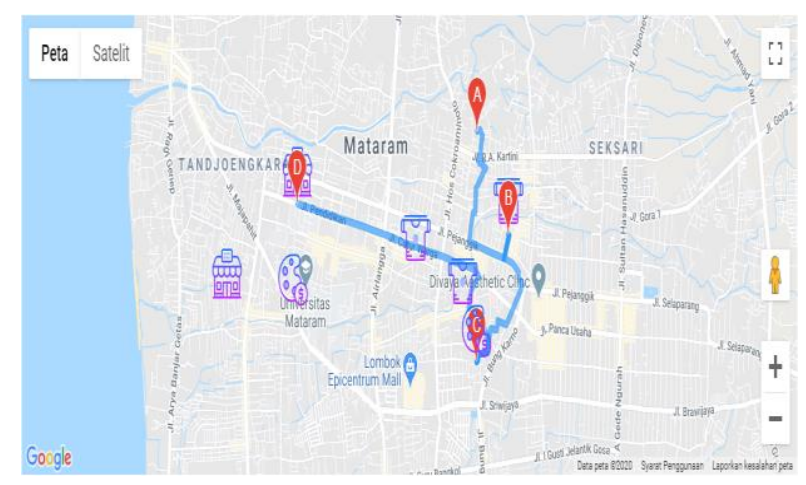

Gambar 4.15. Gambar Hasil fungsi pencarian rute

TABEL XI. TABEL KETETANGGAAN GRAF MASALAH.

\begin{tabular}{|c|l|l|l|l|l|l|l|l|}
\hline \multirow{2}{*}{ Simpul } & KG & J & P & K & J & P & P & K \\
\cline { 2 - 9 } & SL & $\mathbf{1}$ & $\mathbf{2}$ & $\mathbf{3}$ & $\mathbf{4}$ & $\mathbf{5}$ & $\mathbf{6}$ & $\mathbf{7}$ \\
\hline SL & 0 & $\begin{array}{l}5.1 \\
\mathrm{~km}\end{array}$ & $\begin{array}{l}2 \\
\mathrm{~km}\end{array}$ & $\begin{array}{l}2.5 \\
\mathrm{~km}\end{array}$ & $\begin{array}{l}3.3 \\
\mathrm{~km}\end{array}$ & $\frac{\mathbf{1 . 8}}{\mathbf{k m}}$ & $\begin{array}{l}1.9 \\
\mathrm{~km}\end{array}$ & $\begin{array}{l}4.9 \\
\mathrm{~km}\end{array}$ \\
\hline 1 & $\mathrm{x}$ & $\mathrm{x}$ & $\mathrm{x}$ & $\mathrm{x}$ & $\mathrm{X}$ & $\mathrm{x}$ & $\mathrm{x}$ & $\mathrm{X}$ \\
\hline 2 & $\mathrm{x}$ & $\mathrm{X}$ & $\mathrm{x}$ & $\mathrm{x}$ & $\mathrm{x}$ & $\mathrm{x}$ & $\mathrm{x}$ & $\mathrm{X}$ \\
\hline 3 & 0 & $\mathrm{~km}$ & 0 & 0 & $\underline{\mathbf{k m}}$ & 0 & 0 & 0 \\
\hline 4 & $\mathrm{x}$ & $\mathrm{X}$ & $\mathrm{x}$ & $\mathrm{x}$ & $\mathrm{x}$ & $\mathrm{x}$ & $\mathrm{x}$ & $\mathrm{X}$ \\
\hline 5 & 0 & $\mathrm{~km}$ & 0 & $\underline{\mathbf{k m}}$ & $\mathrm{km}$ & 0 & 0 & $\mathrm{~km}$ \\
\hline 6 & $\mathrm{x}$ & $\mathrm{x}$ & $\mathrm{x}$ & $\mathrm{x}$ & $\mathrm{x}$ & $\mathrm{x}$ & $\mathrm{x}$ & $\mathrm{x}$ \\
\hline 7 & $\mathrm{x}$ & $\mathrm{x}$ & $\mathrm{x}$ & $\mathrm{x}$ & $\mathrm{x}$ & $\mathrm{x}$ & $\mathrm{x}$ & $\mathrm{x}$ \\
\hline
\end{tabular}

Dengan Menggunakana algoritma Greedy pada permasalahan pencarian rute terpendek berdasarkan kategori yang dipilih dapat dipecahkan dengan memperhatikan tabel XI graf permasalahan, dimana data yang ada merupakan data dari jarak tempuh sebenarnya dari titik lokasi pengguna menuju lokasi toko ataupun titik lokasi toko menuju titik lokasi toko lainnya yang didapatkan dengan menggunakan google maps untuk mendapat jarak tempuh yang paling pendek sebagai jalur yang digunakan.Berikut cara penyelesaiannya :

a. Pada awalnya node SL akan dijadikan node pertama yang digunakan sebagai titik awal. b. Lalu dari SL dicari jarak tempuh yang paling dekat dengan node yang lainnya dimana didapat yaitu node 5 dengan jarak 1.8 dan jadikan node 5 sebagai node awal.

c. Lalu dari node 5 dicari jarak tempuh yang paling dekat dengan node lainnya dengan kategori selain Pakaian yang merupakan kategori node 5 , dan didapatkan node 3 denga kategori kesenian dengan jarak tempuh 1.6 serta jadikan node 3 sebagai titik awal.

d. Lalu dari node 3 dicari jarak tempuh yang paling dekat dengan node yang berkategori jajanan dan didapatkan node 4 dengan jarak tempuh 3.4.

. Jadi bila disimpulkan maka rute terpendek yang didapatkan adalah SL-5-3-4 dan hasil dari fungsi pada sistem dengan hitungan manual dengan pengujian white box bernilai benar/ valid.

\section{Pengujian Kuisioner Mean Opinion Score.}

Pada pengujian ini, kuesioner diberikan kepada 0 responden setelah responden mencoba sistem. Pengujian ini untuk mengetahui bagaimana persepsi $X$ responden terhadap sistem. Pengujian ini melibatkan $4.8^{30}$ responden yang dipilih dengan random, terdiri dari kmdari wisatawan, admin toko dan staff dinas. Pengujian dilakukan dengan mempresentasikan program kepada

$x$ responden tersebut, responden diberikan kesempatan x untuk mencoba sistem secara langsung, kemudian setellah itu, responden mengisi kuisioner untuk menilai sistem.

Jawaban responden akan dikalkulasi dengan system penskoran yang telah ditetapkan sehingga dapat dianalisis hasil keseluruhan. Kuesioner untuk admin toko dan admin dinas memiliki 5 pertanyaan, yaitu:

a. Apakah website yang dibuat menarik untuk dilihat?

b. Apakah sistem menampilkan informasi berupa titik persebaran toko souvenir di Kota Mataram? c. Apakah sistem dapat menampilkan informasi berupa titik persebaran toko oleh-oleh di Kota Mataram? 
d. Apakah sistem ini dapat membantu admin dalam hal pengelelolaan data toko oleh-oleh di Kota Mataram?

e.Apakah sistem ini bermanfaat dan dapat membantu pada Dinas Perindag dan Toko oleh-oleh di Kota Mataram?

Kuesioner untuk wisatawan atau user terdiri dari terdiri dari 5 pernyataan, yaitu:

a. Apakah website yang dibuat menarik untuk dilihat?

b. Apakah sistem pada website yang dibuat user friendly(mudah digunakan)?

c. Apakah sistem dapat memberikan informasi mengenai data toko oleh-oleh yang diinginkan?

d. Apakah Sistem ini dapat membantu dalam pencarian rute tercepat untuk toko oleh-oleh ?

e. Apakah Sistem ini dapat membantu pengguna dalam hal pemetaan dan memperoleh informasi tentang lokasi oleh-oleh ?

Setiap pertanyaan akan dilengkapi dengan pilihan jawaban sesuai yang dirasakan oleh responden. Pilihan jawabannya adalah sebagai berikut :

a. 5 = Sangat setuju.

b. 4 = setuju.

c. $3=$ Cukup.

d. 2 = Tidak Setuju.

e. 1 = Sangat tidak setuju

Berdasarkan hasil pengujian MOS yang telah dilakukan menunjukan bahwa rata - rata penilain responden user : sangat setuju dengan rata - rata persentasenya adalah $32 \%$, setuju dengan jumlah rata - rata 52\%, sedangkan cukup setuju dengan jumlah rata - rata persentasenya adalah $16 \%$ dan admin: sangat setuju dengan rata - rata persentasenya adalah $36 \%$, setuju dengan jumlah rata - rata $38 \%$, sedangkan cukup setuju dengan jumlah rata - rata persentasenya adalah $26 \%$.

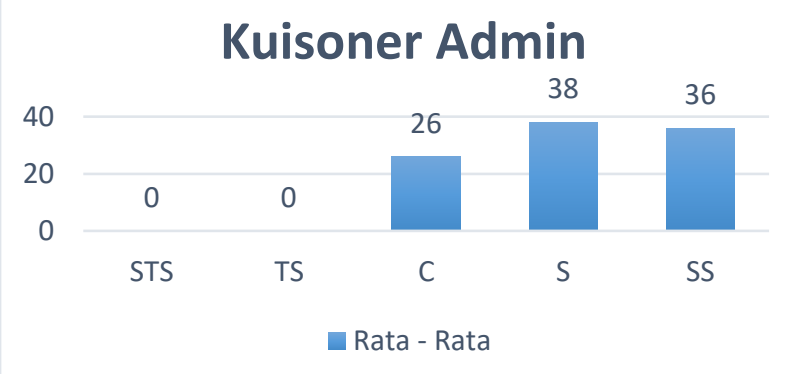

Gambar 16. Grafik persentase jawaban rata-rata responden sisi admin.
Berdasarkan jumlah nilai total sejutu dan sangat setuju maka dapat di simpulkan $74 \%$ responden dari admin setuju terhadap sistem ini.

Sedangkan hasil pengujian kuesioner oleh user diperoleh, hasil dari perhitungan rata - rata seluruh, dapat dilihat pada Gambar 18.

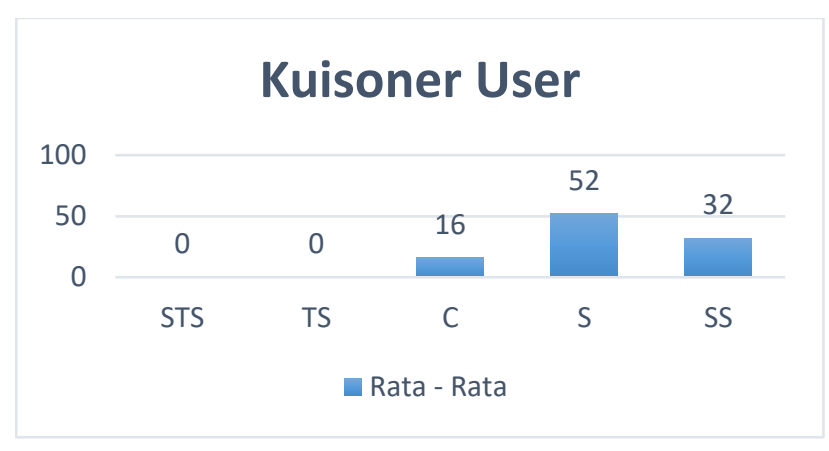

Gambar 17. Grafik persentase jawaban rata-rata responden pengguna sisi user.

Berdasarkan jumlah nilai total sejutu dan sangat setuju maka dapat di simpulkan $84 \%$ responden dari user setuju terhadap sistem ini.

\section{KeSIMPULAN DAN SARAN}

Berdasarkan penelitian dan pengembangan sistem yang dilakukan terdapat beberapa hal yang dapat disimpulkan, antara lain:

a. Berdasarkan hasil pengujian sistem dari sisi pengguna disimpulkan bahwa sistem ini dapat membantu pengguna untuk mencari toko oleh-oleh khas lombok dan menampilkan jalur yang dilalui sesuai kategori toko yang dicari dalam bentuk peta google maps.

b. Berdasarkan hasil pengujian sistem dari sisi admin toko disimpulkan bahwa sistem ini dapat digunakan oleh pemilik toko sebagai media promosi untuk pemasaran produk yang diperdagangkan.

c. Berdasarkan hasil pengujian sistem dari sisi admin dinas disimpulkan sistem ini dapat digunakan untuk pendataan lokasi oleh-oleh khas Lombok dalam bentuk kordinat titik lokasi dalam google maps. .

d. Berdasarkan hasil pengujian sistem ini dapat menampilkan rute pencarian toko dengan menggunakan titik lokasi pengguna dan 20 titik lokasi oleh - oleh dengan keberhasilan 100\%.

e. Berdasarkan hasil pengujian MOS yang telah dilakukan menunjukan bahwa rata - rata penilain responden user : sangat setuju dengan rata - rata persentasenya adalah $32 \%$, setuju dengan jumlah 
rata - rata $52 \%$, sedangkan cukup setuju dengan jumlah rata - rata persentasenya adalah $16 \%$ dan admin: sangat setuju dengan rata - rata persentasenya adalah $36 \%$, setuju dengan jumlah rata - rata $38 \%$, sedangkan cukup setuju dengan jumlah rata - rata persentasenya adalah $26 \%$.

Terdapat beberapa saran yang dapat disapaikan untuk mengembangkan sistem informasi geografis ini yaitu:

a. Untuk pengembangan lainnya diharapkan sistem ini dapat berjalan di platform mobile.

b. Untuk pengembangan selanjutnya diharapka sistem ini dapat diintegrasikan ke sistem sistem yang ada pada dinas kota Mataram.

c. Untuk pengembangan selanjutnya diharapkan sistem ini dapat dikembangkan dalam cangkupan wilyah yang lebih luas.

\section{DAFTAR PUSTAKa}

[1] J. E. Prasetyo, "Sistem Informasi Geografis Pencarian Kuliner Terdekat di Kota Mataram," 2017.

[2] W. Alfarisi, "Pencarian Jalur Terpendek Pengiriman Barang Menggunakan Algoritma A* Studi Kasus Kantor Pos Besar Medan," 2016.

[3] A. C. Purnomo, "Implementasi Algoritma Greedy Pada Layanan Taksi Wisata Berbasis Web," 2014.

[4] A. Cahyany, "Sistem Informasi Geografis ( SIG ) Pemetaan Rute Terpendek UMKM Kota Medan Berbasis Web Menggunakan Algoritma BellmanFord," 2016.

[5] T. Setiadi, "Pencarian Jalur Terpendek Menuju Pom Bensin Pada Kota Semarang Menggunakan Algoritma Dijkstra Berbasis Sistem Informasi Geografis ( Gis )," pp. 53-63, 2012.

[6] J. F. Naibaho, "Pemetaan Informasi Sarana Kesehatan Masyarakat Serta Penyajian Rute Terdekat Menuju Lokasi Sarana Pelayanan Kesehatan Pada Wilayah Kota Berbasis Online," no. Senapati, 2016.
[7] Y. Primadasa, "Pencarian Rute Terpendek Menggunakan Algoritma Dijkstra Pada Sig Berbasis Web Untuk Distribusi Minuman," vol. 2, no. 2, pp. 47-54, 2015.

[8] A. Fajri, E. P. Purwandari, and F. F. Coastera, "Metode Algoritma Dijkstra ( Studi Kasus : Kelurahan Kandang Limun dan Beringin Raya )," vol. 6, no. 1, pp. 69-79, 2018.

[9] K. Setiawan, Supriyadin, I. Santoso, and R. Buana, "Menghitung Rute Terpendek Menggunakan Algoritma A * Dengan Fungsi Euclidean Distance," vol. 2018, no. Sentika, pp. 23-24, 2018.

[10] B. Fahmi, "Penentuan Lokasi Wisata Menggunakan Algoritma Floyd-Warshall di Kabupaten Banjarnegara Berbasis Web-GIS," pp. 1-5, 2014.

[11] R. Munir, Diktat Kuliah IF2251 Strategi Algoritmik. Bandung, 2005.

[12] W. D and P. P, Pemodelan Sistem Berorientasi Obyek dengan UML, vol. 1. Yogyakarta: Graha IImu, 2011.

[13] T. A. Kurniawan, "Pemodelan Use Case (UML): Evaluasi Terhadap beberapa Kesalahan dalam Praktik," in J. Teknol. Inf. dan IImu Komput, 5th ed., 2018.

[14] M. S. Mustaqbal, R. F. Firdaus, and H. Rahmadi, "Pengujian Aplikasi Menggunakan Black box Testing Boundary Value Analysis (Studi Kasus:Aplikasi Prediksi Kelulusan Snmptn)," in Penguji. Apl. Menggunakan Black Box Test. Bound. Value Anal. (Studi Kasus Apl. Prediksi Kelulusan SNMPTN), 2015.

[15] R. Fitriyanti, L. Lindawati, and A. Aryanti, "Analisis Perbandingan Mean Opinion Score Aplikasi VolP Facebook Messenger dan Google Hangouts menggunakan Metode E-Model pada Jaringan LTE," in ELKOMIKA J. Tek. Energi Elektr. Tek. Telekomun. Tek. Elektron., 2018. 